\title{
Regulated redistribution of calretinins in WiDr cells
}

\author{
Beat Schwaller ${ }^{1,2}$ and Brigitte Herrmann ${ }^{1}$ \\ 1 Institute of Histology and General Embryology, University of Fribourg, \\ $\mathrm{CH}-1705$ Fribourg, Switzerland \\ 2 corresponding author: Beat Schwaller, Institute of Histology and General \\ Embryology, University of Fribourg, $\mathrm{CH}-1705$ Fribourg, Switzerland. \\ tel: 02630085 08; fax: 02630097 32; email: Beat.Schwaller@unifr.ch
}

Received 4.7.96; revised 11.10.96; accepted 18.11.96

Edited by M.L. Gougeon

\begin{abstract}
The calcium-binding protein calretinin and the alternatively spliced form calretinin-22k are expressed in the colon adenocarcinoma cell line WiDr. As calcium-binding proteins have been implicated to play a role in cell cycle control, proliferation and differentiation, the levels and intracellular localisation of these two proteins were investigated. The addition of 1,25 -dihydroxy vitamin D3 $\left(10^{-8} \mathrm{M}\right)$ led to a transient translocation of calretinin-22kinto the nucleus, while the cell growth was not affected. The addition of sodium butyrate and hexamethylene bisacteamide which induce markers of enterocyte differentiation decreased the levels of both forms of calretinin more than $90 \%$. The agents which induced differentiation also led to a substantial inhibition of ${ }^{3} \mathrm{H}$-thymidine incorporation ( $>95 \%$ ) which was paralleled by the disappearance of calretinins. We conclude that calretinin and calretinin-22k are associated with the proliferative status of WiDr cells and are almost completely absent in differentiated cells.
\end{abstract}

Keywords: Calcium-binding proteins; colon carcinoma; vitamin D3; differentiation; proliferation; calretinin-22k; nuclear translocation

Abbreviations: $\mathrm{CR}$, calretinin; $\mathrm{CR}-22 \mathrm{k}$, calretinin-22k; CMF, $\mathrm{Ca}^{2+}$ - and $\mathrm{Mg}^{2+}$-free; 1,25- $(\mathrm{OH})_{2} \mathrm{D} 3,1,25$-dihydroxy vitamin D3; HMBA hexamethylene bisacetamide; MTT, 3-(4,5Dimethydiazol-2yl)-2,5-diphenyltetrazolium bromide; NaBT, sodium butyrate; ${ }^{3} \mathrm{H}$-Thy, $\left[\right.$ methyl- $\left.{ }^{3} \mathrm{H}\right]$-thymidine; VDR, vitamin D receptor

\section{Introduction}

Calretinin (CR), a member of the EF-hand family of calciumbinding proteins, is mainly expressed in a specific subset of neurons (Résibois and Rogers, 1992), but has also been detected in several other tissues including thymus (Kiraly et al, 1993), testis (Strauss et al, 1994) and ovary (Pohl et al, 1992). In the colon adenocarcinoma cell line WiDr, a strong $\mathrm{CR}$ immunoreactivity and the presence of CR mRNA was detected (Gotzos et al, 1992) and a more systematic analysis of tumor cells deriving from the colon has revealed that a majority of the cell lines analyzed (10 out of 12 ) expressed this protein to various levels (Gotzos et al, 1996). In most of the cell lines (e.g. WiDr, C0115, SW620) an alternatively spliced transcript leading to a truncated form of $\mathrm{CR}$, named calretinin22k (CR-22k), has been discovered (Schwaller et al, 1995). Splicing of exon 7 to exon 10 (deleting exons 8 and 9) results in a frame shift and a translational stop at codon 15 of exon 10. With a polyclonal antiserum specifically recognizing CR-22k, we have demonstrated that in WiDr cells immunoreactivity for CR-22k was mainly detected in the cytoplasm, as it is also known for the full-length protein (Gander et al, 1996a).

1,25-dihydroxy vitamin D3 [1,25- $\left.(\mathrm{OH})_{2} \mathrm{D} 3\right]$ plays a key role in the regulation of calcium homeostasis and the primary target organs for this vitamin are the intestine and kidney (for a review, see Hannah and Norman, 1994; Norman et al, 1992). In most cases the response to 1,25$(\mathrm{OH})_{2} \mathrm{D} 3$ in the nucleus is mediated through specific receptors of target cells named vitamin $D$ receptors (VDR). While in colonic tumors higher levels of VDR have been measured compared to the normal tissue from where the tumors originated, for rectal tumors the opposite was found (Vandewalle et al, 1994). In tumor cells expressing VDR, a pharmacological action of $1,25-(\mathrm{OH})_{2} \mathrm{D} 3$ on the proliferation and differentiation has been detected in several cases (Niendorf et al, 1987; Tanaka et al, 1990). Either an inhibition or a stimulation of cell growth depending on the concentration of $1,25-(\mathrm{OH})_{2} \mathrm{D} 3\left(10^{-8}\right.$ or $\left.10^{-9} \mathrm{M}\right)$ versus $\left(10^{-10}-10^{-12} \mathrm{M}\right)$ respectively, has been observed in the cell line Caco-2 (Cross et al, 1995). After addition of $1,25-(\mathrm{OH})_{2} \mathrm{D} 3\left(10^{-8} \mathrm{M}\right)$ to the colon carcinoma cell line HT29 , after 5-6 days an increase in maltase activity which serves as a marker of differentiation was observed, but only if cells were grown at low density (Brehier and Thomasset, 1988). 1,25- $(\mathrm{OH})_{2} \mathrm{D} 3$ enhanced the sodium butyrateinduced differentiation, since characteristics of enterocytic differentiation (e.g. elaboration of surface microvilli, secretion of mucin and increased alkaline phosphatase) were observed (Tanaka et al, 1989). In the colon adenocarcinoma cell lines HT-29 and SW480 which express relatively high levels of VDR (Shabahang et al, 1993), the addition of $\left.1,25-(\mathrm{OH})_{2} \mathrm{D} 3\left(10^{-6}-10^{-7}\right) \mathrm{M}\right)$ leads to a concentrationdependant significant inhibition of growth, while cell lines expressing low levels of VDR (e.g. SW620) are not affected by the same concentrations of $1,25-(\mathrm{OH})_{2} \mathrm{D} 3$. In the cell line HT-29 which is closely related to WiDr cells as shown by cytogenetic and isoenzymological data (Chen, 1987), it has been demonstrated that growth and intestinal differentiation are independently regulated (Schroy et al, 1994). In these studies the investigators have used hexamethylene bisacetamide (HMBA) as an inhibitor of cell growth and sodium butyrate (NaBT) which is a potent inducer of differentiation. Although both agents were efficient in inhibition of monolayer growth, only NaBT significantly 
induced markers of differentiation, which was partially attenuated in the presence of HMBA. In summary, in most colon cell lines studied $1,25-(\mathrm{OH})_{2} \mathrm{D} 3$ affects the rate of cell growth and can slowly induce characteristic changes typical for differentiated cells, while sodium butyrate is a rapid inducer of differentiation in most systems studied.

In intestinal cells of rachitic chicks, the calcium-binding protein calbindin-D28k is rapidly induced after administration of $1,25-(\mathrm{OH})_{2} \mathrm{D}$ (Siebert et al, 1982). The mRNA level is increased as early as $3 \mathrm{~h}$ after the application of a dosage of $1,25-(\mathrm{OH})_{2} \mathrm{D} 3$ and the increase persists for more than $24 \mathrm{~h}$. In Madin-Darbey bovine kidney cells, it was demonstrated that calbindin-D28k mRNA was induced by $1,25-(\mathrm{OH})_{2} \mathrm{D} 3\left(10^{-7} \mathrm{M}\right)$ and significantly higher levels of calbindin-D28k were observed at 8 and $24 \mathrm{~h}$ after induction (Gagnon et al, 1994). It is thought that calbindin-D28k present at a higher concentration in induced cells, acts as a cytosolic $\mathrm{Ca}^{2+}$ buffer and presumably facilitates the net diffusional flux of $\mathrm{Ca}^{2+}$ through the cytosol from the luminal to the apical side of the intestine (Feher et al, 1992). CR, the protein most closely related to calbindin-D28k $(60 \%$ identity on the amino acid level) is normally not expressed in the intestine. However, the protein is present in several adenocarcinoma cell lines from the colon (e.g. WiDr, HT29) which do express functional vitamin $D$ receptor (Shabahang et al, 1993), while calbindin-D28k was absent in the CR-immunoreactive colon cell lines (J.-Ch. Gander, unpublished data). The aim of this study was to investigate if $1,25-(\mathrm{OH})_{2} \mathrm{D} 3$ and other substances, acting on the proliferation or differentiation of the cell line WiDr may influence the level and distribution of CR or the alternatively spliced transcript CR-22k.

Here we report that during the first 2 days of treatment, the levels of CR mRNA and proteins are slightly upregulated by $1,25-(\mathrm{OH})_{2} \mathrm{D} 3$ while the combination of NaBT and HMBA reduced the level of calretinins. On the other hand, CR-22k and possibly CR undergo a transient translocation from the cytosol into the nucleus. During the differentiation of WiDr cells induced by NaBT and HMBA, the disappearance of cells in $S$ phase is paralleled by a continuous loss of calretinins which is almost complete after 11 days of treatment.

\section{Results}

\section{Effects of 1,25-(OH) $)_{2}$ D3 on cell growth of WiDr cells}

The effects of 1,25- $(\mathrm{OH})_{2}$ dihydroxyvitamin D3 $\left(1,25-(\mathrm{OH})_{2} \mathrm{D} 3\right)$ on the proliferation of $\mathrm{WiDr}$ cells was investigated for concentrations between $10^{-6}-10^{-10} \mathrm{M}$ for periods of 1 to 7 days. After trypsinisation cells were grown in normal culture medium for $48 \mathrm{~h}$ before the medium was replaced. Different controls were carried out to exclude non-specific effects. WiDr cells were either grown in medium with normal serum, medium with stripped serum (by activated charcoal) or medium with stripped serum containing $0.1 \%(\mathrm{v} / \mathrm{v})$ ethanol and no statistical significant differences were observed. The latter one was used for subsequent experiments including the various concentrations of $1,25-(\mathrm{OH})_{2} \mathrm{D} 3$. While concentrations of $10^{-6}$ and $10^{-7} \mathrm{M}$ had a significant inhibitory effect on the cell growth (Figure 1), the lower concentrations $10^{-8}-$
$10^{-10} \mathrm{M}$ did not affect the growth of WiDr cells. The inhibition was most pronounced with $10^{-6} \mathrm{M} 1,25-(\mathrm{OH})_{2} \mathrm{D} 3$ after 7 days ( $\approx 80 \%$ inhibition compared to control cells), but was mainly the result of a massive detachment of cells after $24-48 \mathrm{~h}$ which then most likely died (not shown). Also the morphology of the remaining cells changed dramatically. WiDr cells display a typically epithelial-like morphology and are very

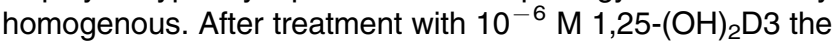
remaining cells showed a poorly defined irregular morphology indicative of cytotoxic effects (not shown). To a lesser extent the same results were obtained after the application of

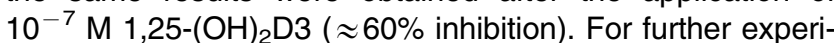
ments, concentrations of $\leqslant 10^{-8} \mathrm{M}$ which maintained the structural characteristics of WiDr cells were employed.

\section{Effects of 1,25-(OH $)_{2}$ D3 on CR mRNA, protein concentration and subcellular localisation}

In WiDr cells deriving from a colon adenocarcinoma, experiments were performed to investigate the role of 1,25$(\mathrm{OH})_{2} \mathrm{D} 3$ on the expression of $\mathrm{CR}$. For this reason, the levels of CR mRNA isolated from cells treated with $10^{-8} \mathrm{M} 1,25-$ $(\mathrm{OH})_{2} \mathrm{D} 3$ after 24 and $48 \mathrm{~h}$ were compared to untreated cells and on the Northern blot a small increase of CR mRNA was observed after $48 \mathrm{~h}$ of treatment (Figure 2). Western blot experiments with fractions of soluble proteins isolated from WiDr cells after 1 to 11 days are shown in Figure 3 . The signals in the Western blot (detected by the polyclonal antiserum 7696 raised against full length CR) in untreated cells was more or less constant with a small increase after 24-48 h. A similar pattern was also observed after treatment with $10^{-8} \mathrm{M} 1,25-(\mathrm{OH})_{2} \mathrm{D} 3$. To confirm these results, protein samples isolated after 24 and $48 \mathrm{~h}$ were directly compared on the same gel and the results are shown in Figure 5. An increase of cytosolic CR was most prominent after $48 \mathrm{~h}$ (Figure 5).

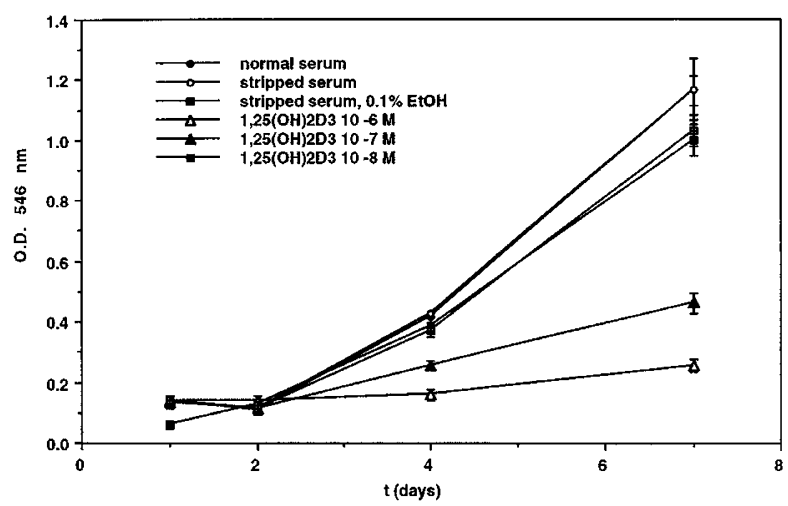

Figure 1 Cell growth assay of WiDr cells treated with $1,25-(\mathrm{OH})_{2} \mathrm{D}_{3}$. WiDr cells $\left(10^{3}\right.$ cells/well) grown in 96 -well titer plates were incubated with medium containing $1,25-(\mathrm{OH})_{2} \mathrm{D} 3\left(10^{-6} \mathrm{M}-10^{-8} \mathrm{M}\right)$ for up to 7 days. The cell number was determined in the MTT assay as described under Materials and Methods. The results are the average of three independent experiments. The curves for $1,25-(\mathrm{OH})_{2} \mathrm{D} 3\left(10^{-9} \mathrm{M}\right.$ and $\left.10^{-10} \mathrm{M}\right)$ are identical as for untreated cells (not shown). 
Characteristic differences between 1,25- $(\mathrm{OH})_{2}$ D3-treated and control cells were observed after immunohistochemical staining of WiDr cells using the antiserum 7696. The staining in untreated WiDr cells is mainly cytosolic, the nuclei are almost negative and mitotic cells are strongly stained (Figure 4.5). After the addition of $1,25-(\mathrm{OH})_{2} \mathrm{D} 3$ for $24 \mathrm{~h}$ two populations of cells were visible. On one hand strongly ir-positive cells where staining also included the nucleus and on the other hand, cells which were almost completely immuno-negative (Figure 4.6). $24 \mathrm{~h}$ later, no more immunonegative cells were present and the majority of the immunoreactivity was detected in the nucleus (Figure 4.7). A qualitatively similar situation was also observed after $96 \mathrm{~h}$ (Figure 4.8), while after 7 days of treatment immunostaining was the same as in control cells (not shown, but similar as in Figure 4.5). As the polyclonal antiserum 7696 can not distinguish between full-length CR and the alternatively spliced gene product CR-22k, a polyclonal antiserum which specifically recognizes $\mathrm{CR}-22 \mathrm{k}$ (25A, (Gander et al, 1996a)) was used to immunostain WiDr cells grown under identical conditions as for the previous experiment (Figure 4.1-4.4). The staining with the

$24 \mathrm{~h}$

$48 \mathrm{~h}$

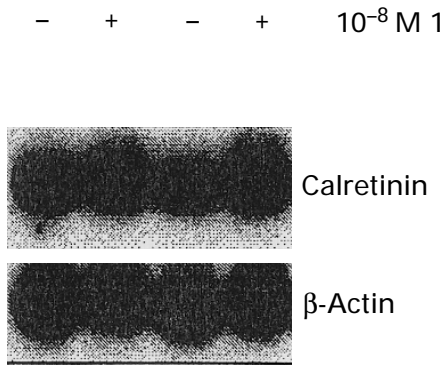

Figure 2 Northern blot analysis of CR mRNA isolated from WiDr cells in the presence or absence of $1,25-(\mathrm{OH})_{2} \mathrm{D} 3\left(10^{-8} \mathrm{M}\right)$ after $24 \mathrm{~h}$ and $48 \mathrm{~h} .10 \mu \mathrm{g}$ of total RNA were separated on $1 \%$ agarose-formaldehyde gel and hybridized with a CR cDNA probe of $1.5 \mathrm{~kb}$. The same filter was then rehybridized with a cDNA probe $(1.0 \mathrm{~kb})$ for human $\beta$-actin.

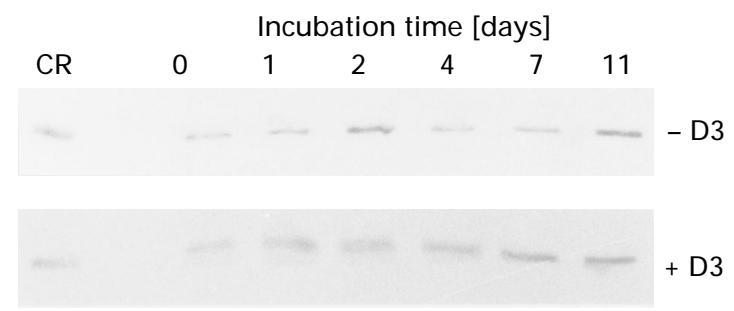

Figure 3 Western blot analysis of soluble extracts of WiDr cells. WiDr cells were grown in the presence or absence of $1,25-(\mathrm{OH})_{2} \mathrm{D} 3\left(10^{-8} \mathrm{M}\right)$ for up to 11 days. Soluble proteins were isolated and separated by SDS-PAGE (12.5\%). Immunostaining of the filter was carried out using the polyclonal antiserum 7696 against $C R$. In the left lanes, purified human recombinant CR was used as a standard. antiserum against CR-22k in untreated cells was almost identical as the staining with the antiserum 7696 (Figure 4.1). After $1,25-(\mathrm{OH})_{2} \mathrm{D} 3$-treatment for $48-96 \mathrm{~h}$ (Figure 4.3 and 4.4) CR-22k immunoreactivity was mainly detected in the nucleus, while the cytoplasmic staining was significantly reduced. After longer treatment (7 to 11 days), the distribution was similar as in untreated cells (not shown) and confirmed the transient nature of this phenomenon. These results were a first indication that CR-22k translocates into the nucleus as a result of the application of $1,25-(\mathrm{OH})_{2} \mathrm{D} 3$. Winsky and Kuznicki, (1995) have shown before that antibody recognition of calcium-binding proteins depends on their calcium-binding status. In order to confirm that the results obtained by immunohistochemical stainings were the result of an accumulation of $\mathrm{CR}$ and/or CR-22k in the nucleus and not due to an altered recognition by the
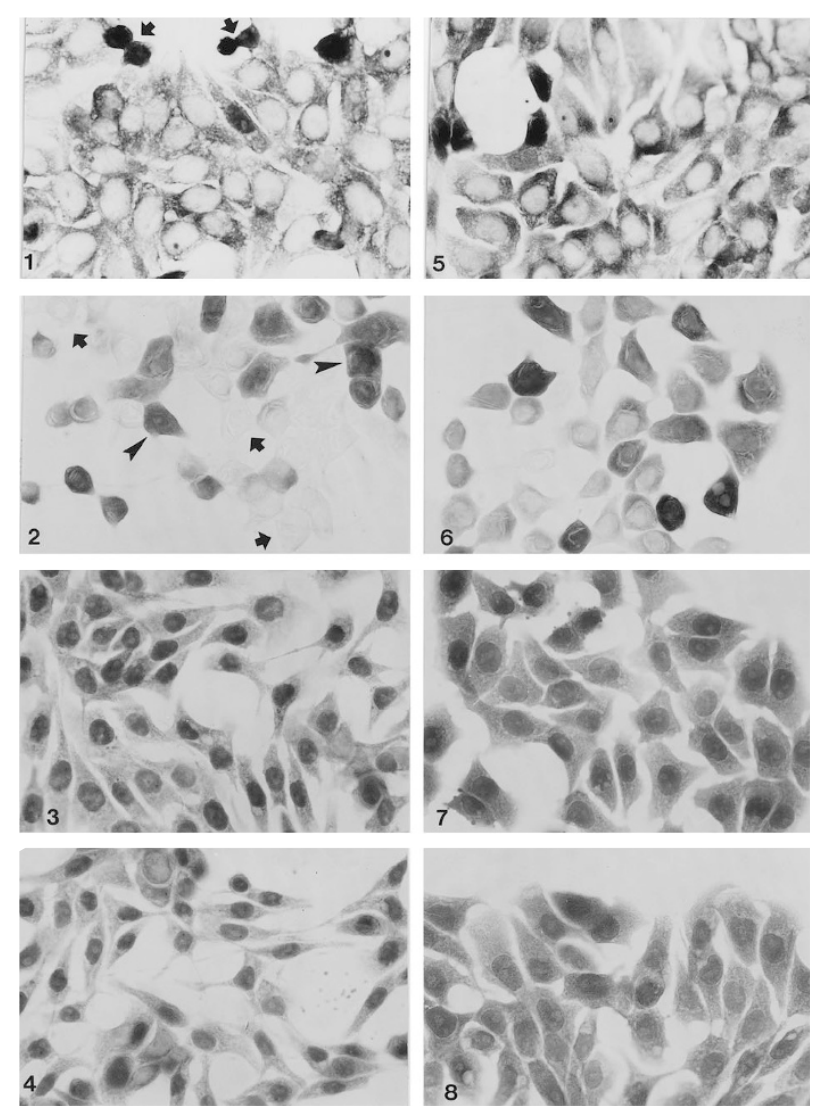

Figure 4 Immunohistochemical staining of WiDr cells treated with 1,25 $(\mathrm{OH})_{2} \mathrm{D} 3\left(10^{-8} \mathrm{M}\right)$. WiDr cells were immunostained with the antiserum specific for CR-22k $(25 \mathrm{~A})(1-4)$ or an antiserum recognising all forms of $\mathrm{CR}$ (7696) (5-8) (1) Untreated control cells show a cytoplasmic distribution of CR$22 \mathrm{k}$ and some strongly stained cells (arrows) which just have terminated mitosis. (2) After $24 \mathrm{~h}$ treatment with $1,25-(\mathrm{OH})_{2} \mathrm{D}_{3}\left(10^{-8} \mathrm{M}\right)$ the distribution of CR-22k-ir is very heterogeneous with some intensely stained cells (arrowheads), but also WiDr cells which are almost negative (arrows). (3) After $48 \mathrm{~h}$ a translocation of CR-22k into the nucleus is visible in a majority of cells, while in the cytoplasm the staining is heterogeneous and relatively weak. (4) After $96 \mathrm{~h}$, the majority of cells show a strong CR-22k-ir in the nucleus. (58) WiDr cells treated as in $(1-4)$ were stained with the antiserum 7696 which recognises all forms of $\mathrm{CR}$. The distribution of the immunoreactivity is very similar, except that the cytoplasmic staining after the addition of $1,25-(\mathrm{OH})_{2} \mathrm{D} 3$ remains quite strong $(7,8$ and compared to 3,4$)$. 


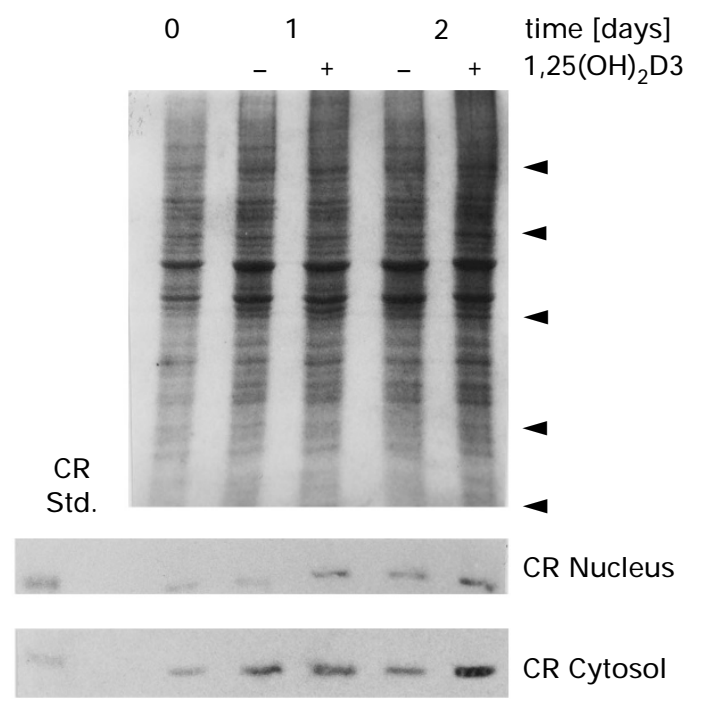

Figure 5 Coomassie stain and Western blot analysis of proteins isolated from a nuclear fraction and Western blot of total soluble proteins isolated from WiDr cells in the presence or absence of $1,25-(\mathrm{OH})_{2} \mathrm{D} 3\left(10^{-8} \mathrm{M}\right)$. Proteins from a nuclear fraction of WiDr cells were isolated, separated by SDS-PAGE $(12.5 \%)$ and stained by Coomassie Blue (upper panel). The positions of the molecular weight marker proteins are indicated by arrows and the sizes are from top to bottom: $97,68,43,31$ and $21 \mathrm{kDA}$. Proteins from an identical ge were transferred to membranes and CR was detected by the antiserum 7696 (middle panel). The CR standard is identical as in Figure 3. Total soluble proteins were extracted from parallel cultures and CR immunoreactivity was detected as before (lower panel).

antiserum 7696, Western blot experiments with either cytosolic or nuclear fractions of WiDr cells were performed. In cytosolic extracts isolated after $48 \mathrm{~h}$ a small increase of cytosolic CR was detected in 1,25-(OH) 2 D3treated cells (Figure 5). In the nuclear extracts the amount of nuclear CR was slightly increased after $24 \mathrm{~h}$ and $48 \mathrm{~h}$ in 1,25- $(\mathrm{OH})_{2}$ D3-stimulated WiDr cells (Figure 5). Western blot experiments with the antiserum 25A to detect CR-22k were negative most likely as the result of relatively low amounts of CR-22k and furthermore to a low affinity of the antiserum 25A for SDS-denatured CR-22k as described before (Gander et al, 1996a).

\section{Effects of a combination of sodium butyrate and hexamethylene bisacetamide on cell growth of WiDr cells}

Sodium butyrate (NaBT) in combination with the proliferation inhibitor hexamethylene bisacetamide (HMBA) has been shown to induce differentiation in the cell line HT-29 (Schroy et al, 1994) from which the cell line WiDr is a derivative. First, we decided to investigate if the results obtained with HT-29 cells could be reproduced using WiDr cells and to study the effects of this procedure on CR levels and distribution. WiDr cells were grown in the presence of NaBT and HMBA (1$5 \mathrm{mM}$ each) for up to 11 days and the results are shown in Figure 6. A significant decrease of cell growth was measured in the presence of 2.5 and $5 \mathrm{mM}$, while $1 \mathrm{mM}$ of each only had an effect up to day 6 while at 11 days no significant differences compared to control cells were detected. After the incubation

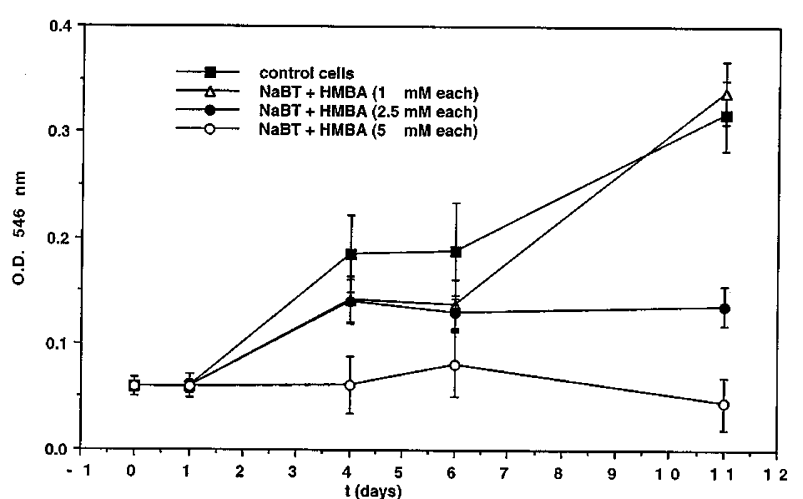

Figure 6 Cell growth assay of WiDr cells treated with hexamethylene bisacetamide (HMBA) and sodium butyrate (NaBT) (5 mM each). WiDr cells $\left(10^{3}\right.$ cells/well) grown in 96 -well titer plates were incubated with medium containing HMBA $\pm \mathrm{NaBt}(1-5 \mathrm{mM}$, each) for up to 11 days. The cell number was determined in the MTT assay as in Figure 1. The results shown are the average of three independent experiments.

with $5 \mathrm{mM}$ each, the cell morphology changed from the epitheloid form as cells formed compact cell clusters or sometimes showed a tendency to generate flat foci (not shown) as had been reported for HT-29 cells previously after treatment with sodium butyrate (Tanaka et al, 1989). For subsequent studies the concentration showing maximal effects (5 $\mathrm{mM}$ each) were used.

\section{Localisation of CR-22k in NaBT- and HMBA-treated WiDr cells}

The amount of CR in total extracts of control or treated cells was compared by Western blot and showed a persisting decrease of $\mathrm{CR}$ and an almost complete disappearance after 11 days of treatment (Figure 7A). The same result was obtained when the total amount of calretinins was quantified by a sandwich ELISA (Figure 9B) using the polyclonal antiserum 7696. However, a small increase in the amount of $\mathrm{CR}$ in the nuclear fraction after 4 days of treatment seemed evident (Figure 7B).

As we had hypothesized that mainly CR-22k accumulates in the nucleus, we developed a sandwich ELISA as described in the Materials and Methods section with the polyclonal antiserum against CR-22k (25A) and compared the values obtained with the polyclonal serum 7696. $5 \mu \mathrm{g}$ of nuclear protein extract was added per well and the concentration of CR-22k or the total amount of calretinins were determined using the antisera 25A and 7696, respectively. After treatment with $\mathrm{NaBT}$ and HMBA for 4 days, only a small difference was observed with the antiserum $7696 \quad(\approx 30 \%$ increase compared to the control), while a significant difference in the amount of CR-22k was evident. Untreated WiDr cells (after $24 \mathrm{~h}$ in culture) contained $60 \pm 20 \mathrm{pg}$ of nuclear CR-22k per $10 \mu \mathrm{g}$ of nuclear protein and after 4 days in culture the values increased slightly to $100 \pm 24 \mathrm{pg}(100 \%)$ On the other hand, $294 \pm 28 \mathrm{pg}(\approx 300 \%)$ of CR-22k per $10 \mu \mathrm{g}$ of nuclear protein were found in NaBT+HMBA treated cells after 4 days. 

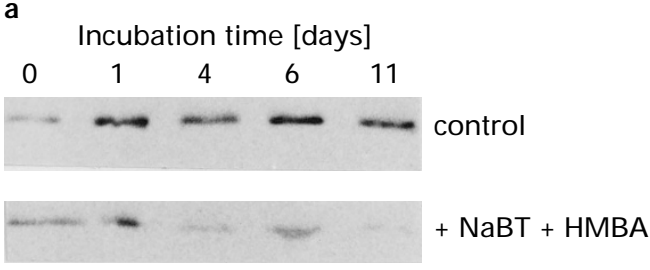

b
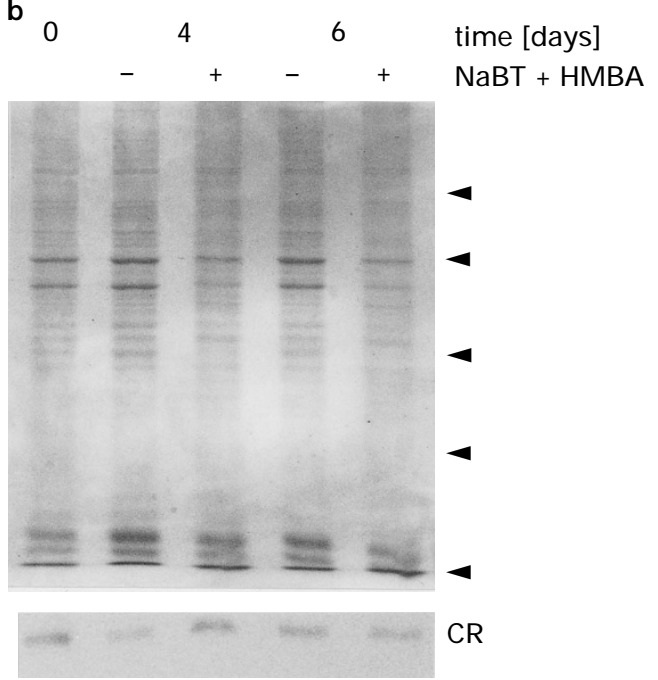

Figure 7 Western blot analysis of WiDr cells treated with HMBA and NaBT (5 mM each). (A) WiDr cells were grown in the presence or absence of HMBA and $\mathrm{NaBT}$ ( $5 \mathrm{mM}$ each) for 1 to 11 days. Equal amounts of total soluble proteins were separated by SDS-PAGE (12.5\%) and transferred onto membranes. For the immunodetection of $\mathrm{CR}$, the antiserum 7696 was used. (B) Soluble proteins from a nuclear fraction of WiDr cells were either stained with Coomassie Blue (upper panel) or immunostained with the antiserum 7696 (lower panel, only region with the specific CR signal shown). The molecular weight marker proteins in the Coomassie stain are marked by arrows and the sizes are (from top to bottom) 97, 68, 43, 31 and $21 \mathrm{kDa}$.
Immunohistochemical staining of WiDr cells treated with $\mathrm{NaBT}+\mathrm{HMBA}$ for 4 days with the CR-22k-specific antiserum clearly demonstrated that the majority of the immunoreactivity was localized in the nucleus (Figure $8 \mathrm{~B}-\mathrm{C}$ ) similar to the earlier findings obtained after treatment with 1,25$(\mathrm{OH})_{2}$ D3. As a comparison cells were also immunostained with antiserum 7696 (Figure 8A) and the staining was comparable to $1,25-(\mathrm{OH})_{2}$ D3-treated cells.

\section{Comparison of cell proliferation and CR concentration}

In the last series of experiments we attempted to correlate the concentration of $\mathrm{CR}$ present in WiDr cells (after treatment with either 1,25-(OH $)_{2} \mathrm{D} 3$ or NaBT+ HMBA) with the proliferation. For this purpose, we measured the ${ }^{3} \mathrm{H}$-thymidine incorporation after the different treatments for up to 11 days and compared these results with $\mathrm{CR}$ values from total extracts of untreated WiDr cells. ${ }^{3} \mathrm{H}$-thymidine values were corrected for the number of cells present in each well as determined by the MTT assay. For cells treated with $1,25-(\mathrm{OH})_{2} \mathrm{D} 3\left(10^{-8} \mathrm{M}\right){ }^{3} \mathrm{H}-$ thymidine incorporation was not different than the values measured in control cells (Figure 9A). The quantity of calretinins in the cytosolic extracts as quantitated by ELISA with the antiserum 7696 showed a slight increase after $24 \mathrm{~h}$ (Figure 9B), but the difference was not highly significant due to the rather large standard deviations. Nevertheless, the results are in accordance with the slightly elevated CR concentrations after 24 and $48 \mathrm{~h}$ in $1,25-(\mathrm{OH})_{2} \mathrm{D} 3$ treated cells. In contrast, ${ }^{3} \mathrm{H}$-thymidine incorporation was inhibited by almost 95\% (compared to untreated cells) in NaBT+HMBA-treated cells and paralleled the disappearance of CR from $97 \mathrm{pg} / 5 \mu \mathrm{g}$ total soluble extract in control cells to approximately $3 \mathrm{pg} / 5 \mu \mathrm{g}$ ( $\approx 3 \%$ of control) in NaBT+HMBA-treated cells (Figure $9 \mathrm{~B}$ ). This demonstrates the close correlation between the presence of calretinins and cell proliferation.
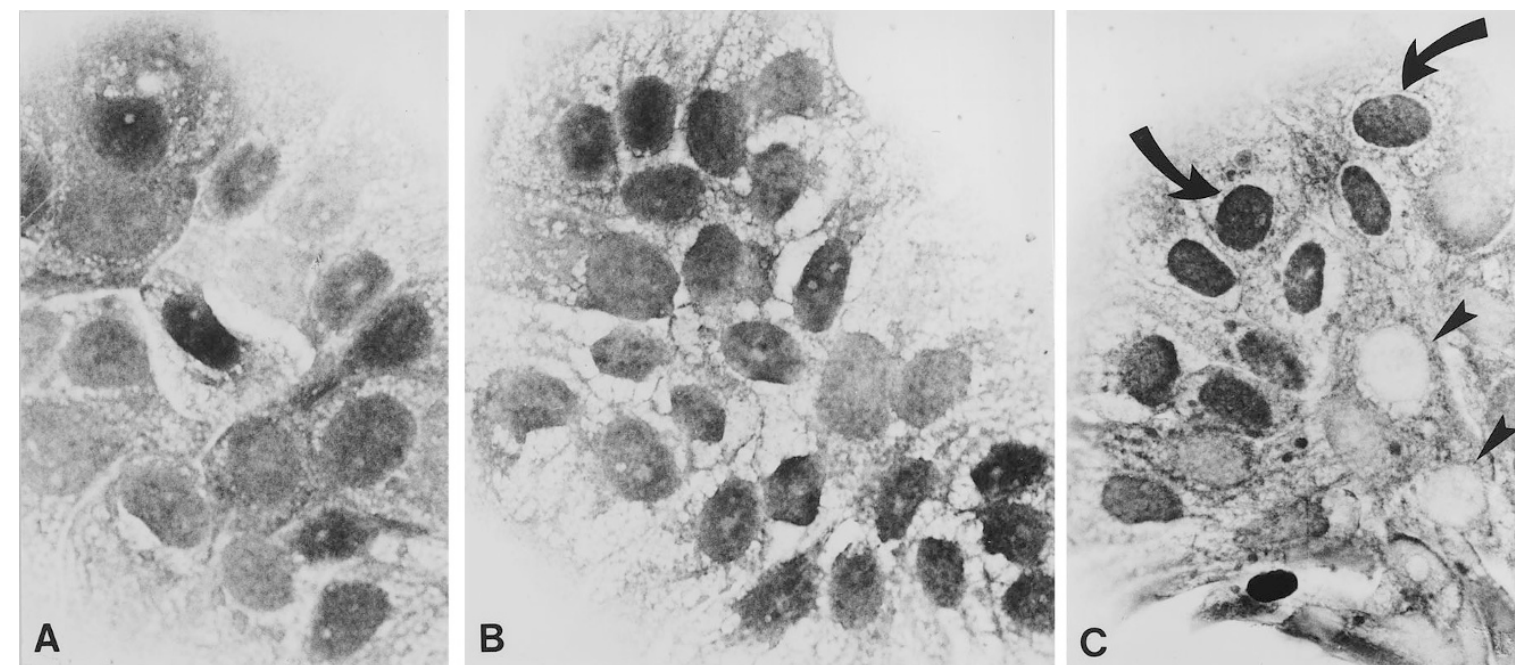

Figure 8 Effect of HMBA and sodium butyrate on CR-22k distribution. WiDr cells treated with HMBA and NaBT ( $5 \mathrm{mM}$ each) for $96 \mathrm{~h}$ were immunostained with the antisera $25 \mathrm{~A}$ specific for CR-22k (B, C) or with antiserum $7696(\mathbf{A})$. The distribution of CR-22k is very similar compared with 1,25-(OH) $)_{2} \mathrm{D} 3-$ treated WiDr cells after $48 \mathrm{~h}$. To exclude non-specific staining of the nucleus, a picture of treated WiDr cells is shown (C) where CR-22k is present in the nucleus only in a fraction of cells (arrows), while in some cells no immunoreactivity is visible in the nucleus (arrowheads). 

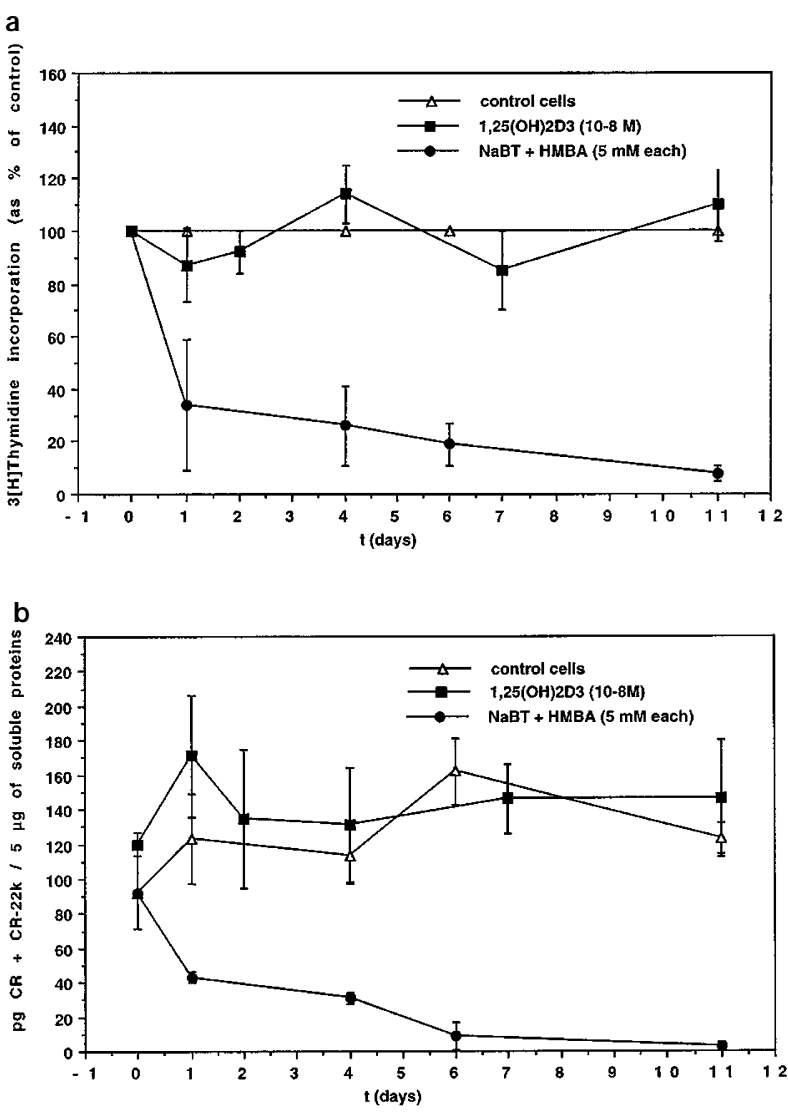

Figure 9 Comparison of $\left.{ }^{3} \mathrm{H}\right]$-thymidine incorporation and quantification of CR content in WiDr cells treated with $1,25-(\mathrm{OH})_{2} \mathrm{D}_{3}\left(10^{-8} \mathrm{M}\right)$ or the mixture of HMBA+NaBT. (A) WiDr cell proliferation was measured by the incorporation of $\left[{ }^{3} \mathrm{H}\right]$-thmyidine after the two different treatments and compared to untreated control cells. Values are in triplicates and the average from two different experiments. (B) The amount of CR in the total soluble fraction of WiDr cells was determined by the sandwich ELISA as described above after the two different treatments. Values are expressed as pg of CR per $5 \mu \mathrm{g}$ of total soluble proteins, were measured in triplicates and are the average of two independent experiments.

\section{Discussion}

\section{Methodological considerations}

Two different polyclonal antisera were used: the antiserum 7696 which had been raised against the human recombinant CR (Schwaller et al, 1993) and the antiserum 25A (Gander et al, 1996a) which recognizes the 15 C-terminal amino acids of CR-22k which are not present in the full-length protein. As the antiserum 7696 recognizes epitopes present in both CR and CR-22k (Schwaller et al, 1995), in immunohistochemical stainings and in the ELISA test, the two forms of CR can not be distinguished. In Western blots, the identification of $C R$ is evident as CR-22k has a different molecular mass (29 and $23 \mathrm{kDa}$, respectively) and the proteins can be easily separated by SDS-PAGE. Under the experimental conditions used, the protein CR-22k is recognized by the antiserum 7696, but with a lower affinity (B. Schwaller, unpublished results). In addition, preliminary data indicate that $\mathrm{CR}-22 \mathrm{k}$ in WiDr cells is present at an approximately five times lower concentration than CR (Gander et al, 1996a). For this reason, under the conditions used in this study, CR-22k is not detectable in Western blots with the antiserum 7696. Furthermore, the protein CR-22k is only poorly recognized in Western blots of SDS-denatured proteins by the antiserum 25A (Gander et al, 1996a). Therefore, to allow for a quantification of these two proteins, a sandwich ELISA has been developed which uses a goat polyclonal antiserum against $\mathrm{CR}$ as the specific surface coating of the plates and the two antisera 7696 and 25A for specific 'detection'. The ELISA using the antiserum 25A against CR-22k enables a selective detection of CR-22k without interference from fulllength CR while the antiserum 7696 detects the total amount of CR and CR-22k.

\section{Effects of 1,25-(OH) $)_{2} \mathrm{D} 3$ or HMBA+NaBT on the level and subcellular distribution of $\mathrm{CR}$ and $\mathrm{CR}-22 \mathrm{k}$}

The effects of $1,25-(\mathrm{OH})_{2} \mathrm{D} 3$ on the proliferation or induction of differentiation have been documented previously (Brehier and Thomasset, 1988; Giuliano et al, 1991; Lointier et al, 1987). Often the application of $1,25-(\mathrm{OH})_{2} \mathrm{D} 3$ has a biphasic effect. Relatively high doses $\left(\geqslant 10^{-8} \mathrm{M}\right)$ lead to an inhibition of proliferation while lower concentrations can either have no effects or even stimulate cell growth as in the case of Caco-2 cells (Cross et al, 1995). For HT-29 cells, the addition of 1,25$(\mathrm{OH})_{2} \mathrm{D} 3\left(10^{-6} \mathrm{M}\right)$ and analogs either induced apoptosis or differentiation along with a constant cell cycle blockage in G1 depending on the stage of the cell culture. (Vandewalle et al, 1995). In our study a similar effect was observed. Concentrations up to $10^{-7} \mathrm{M}$ led to a significant inhibition of WiDr cell growth and cell death while concentrations of 1,25- $(\mathrm{OH})_{2} \mathrm{D} 3$ smaller than $10^{-8} \mathrm{M}$ seemed to have no effect on WiDr cell growth. The most striking difference compared to untreated control cell was the localisation of CR-22k and CR as evidenced by immunohistochemistry. While in control cells $\mathrm{CR}$ and CR-22k are mainly present in the cytosol as shown before (Gotzos et al, 1992; Gander et al, 1996a), the addition of $1,25-(\mathrm{OH})_{2} \mathrm{D} 3\left(10^{-8} \mathrm{M}\right)$ led to a transient translocation of $\mathrm{CR}-22 \mathrm{k}$ and to a lesser extent also of CR into the nucleus. Although WiDr cells are very homogenous with respect to size and morphology, variations in their responsiveness to $1,25-$ $(\mathrm{OH})_{2} \mathrm{D} 3$ were evident as this translocation was not observed in all cells. An explanation for these findings could be the fact that in an asynchronous cell population not all cells equally respond to a stimulatory signal depending on their phase in the cell cycle as also suggested by Vandewalle in the HT-29 cell system (Vandewalle et al, 1995). Another possibility is that levels of VDR or other components of the $1,25-(\mathrm{OH})_{2} \mathrm{D} 3$ signal transduction pathways are different although no obvious differences are detected between individual cells. For example, in the cell line HT-29 the surface marker 29-15 is specifically expressed in some cell clusters while this marker is completely absent in others (Schroy et al, 1989).

Further evidence for the translocation process comes from the ELISA experiments where the presence of CR-22k or $\mathrm{CR}$ in nuclear extracts from WiDr cells treated with HMBA and sodium butyrate was quantified. The amount of CR-22k was increased approximately threefold while the ELISA with the antiserum 7696 which recognizes all forms of calretinins only showed an increase in the order of $30 \%$. 
This further supports the notion that mainly CR-22k translocates into the nucleus. In Western blots of nuclear extracts also an increase of full-length $C R$ was evident which was most prominent after $24 \mathrm{~h}$. Since in 1,25$(\mathrm{OH})_{2} \mathrm{D} 3$ treated cells the levels of CR mRNA and calretinins were slightly elevated after $24-48 \mathrm{~h}$, the observed increase of $\mathrm{CR}$ in the nucleus might only reflect the global increase of $C R$ and not necessarily be the result of a specific translocation process. In tissue from rat cerebellum, Winsky and Kuznicki (1995) have demonstrated before that a small fraction of CR molecules are present in various cell compartments (e.g. nucleus, mitochondria, etc.), although a majority of the protein is detected in the cytosolic fraction.

Möckel and Fischer (1994) have shown that in primary cultures of neurons exposed to hypoxia, a small population $(3-5 \%)$ of CR-containing neurons preferentially survived and that in several occasions an increased CR-immunoreactivity was found in the nucleus after this treatment (V. Möckel, personal communications). This translocation into the nucleus may represent a mechanism to protect the nucleus from degradation in the case of a prolonged increase of the intracellular calcium concentration. Our findings are in accordance with results from Gagnon et al 1994) where in Madin-Darby bovine kidney (MDBK) cells which express significant levels of calbindin-D28k, immunoreactivity has been detected in the nucleus, particularly in $1,25-(\mathrm{OH})_{2} \mathrm{D} 3$ treated cells. In osteogenic sarcoma ROS $17 / 2.8$ cells, the application of $1,25-(\mathrm{OH})_{2} \mathrm{D} 3$ to the cell culture leads to a transient increase of $\left[\mathrm{Ca}^{2+}\right]_{\mathrm{i}}$ (Civitelli et al, 1990). However, this transient increase in ROS $17 / 2.8$ cells occurs within $30-60 \mathrm{~s}$ after the addition of $1,25-(\mathrm{OH})_{2} \mathrm{D} 3$ and returns to baseline within $40-60 \mathrm{~s}$. In rat colonic epithelium the addition of $1,25-(\mathrm{OH})_{2} \mathrm{D} 3\left(10^{-8} \mathrm{M}\right)$ to isolated colonocytes resulted in a transient increase of $\left[\mathrm{Ca}^{2+}\right]_{\mathrm{i}}$ (Wali et al, 1990) and also in WiDr cells in preliminary experiments, we have observed a small increase of $\left[\mathrm{Ca}^{2+}\right]_{i}$ (not shown). As the first appearance of $\mathrm{CR}$ in the nucleus of WiDr cells occurs later $(24-48 \mathrm{~h}$ after the addition), this excludes that this is an immediate response to an elevated concentration of $\left[\mathrm{Ca}^{2+}\right]_{i}$. Nevertheless, the signals $1,25-(\mathrm{OH})_{2} \mathrm{D} 3$ or $(\mathrm{HMBA}+\mathrm{NaBT})$ finally led to a redistribution of $\mathrm{CR}-22 \mathrm{k}$ and possibly $\mathrm{CR}$ into the nucleus.

The combination of hexamethylene bisacetamide (HMBA) and sodium butyrate (NaBT) has been shown to effectively inhibit the proliferation of HT-29 cells and to induce differentiation which we also observed for WiDr cells. As for the treatment with $1,25-(\mathrm{OH})_{2} \mathrm{D} 3$ a transient accumulation of $\mathrm{CR}-22 \mathrm{k}$ in the nucleus was evident, which was further supported by ELISA results. In contrast to the treatment with $1,25-(\mathrm{OH})_{2} \mathrm{D} 3$, the levels of $\mathrm{CR}$ and CR-22k gradually decreased and were almost zero after 11 days of treatment. In parallel the cell proliferation as assayed by incorporation of $\left[{ }^{3} \mathrm{H}\right]$-thymidine decreased significantly and was less than $10 \%$ compared to control cells. These results indicate that the presence of CR and CR-22k in WiDr cells is a marker for proliferating and mainly undifferentiated cells, while the absence of calretinins is linked to their differentiated state. The question remains if the two phenomena, namely the concentration of either CR or $\mathrm{CR}-22 \mathrm{k}$ and the proliferation of these cells are directly correlated. Previously we have down-regulated the expression of calretinins with antisense oligodeoxynucleotides (Gander et al, 1996b) and we could demonstrate that downregulation of $\mathrm{CR}$ and $\mathrm{CR}-22 \mathrm{k}$ lead to an inhibition of proliferation. This demonstrated that the presence of calretinins in WiDr cells seemed to be a prerequisite for their proliferative status. In summary, the addition of either $1,25-(\mathrm{OH})_{2} \mathrm{D} 3$ or the combination of HMBA and sodium butyrate leads to a transient translocation of CR-22k and possibly also of CR into the nucleus of WiDr cells. It is hypothesized that these proteins might exert a protective role in order to buffer a prolonged increase in nucleic $\left[\mathrm{Ca}^{2+}\right]$. Prolonged incubation with a mixture of HMBA and sodium butyrate which induces the differentiation of WiDr cells leads to a down-regulation of calretinins, while 1,25$(\mathrm{OH})_{2} \mathrm{D} 3\left(\leqslant 10^{-8} \mathrm{M}\right)$ does not significantly induce differentiation and does not affect the level of expression of both proteins. Our data further document the involvement of calretinins in WiDr cells in the phenomena related to proliferation and differentiation.

\section{Materials and Methods}

\section{Cell culture techniques}

WiDr cells were cultivated as a monolayer at $37^{\circ} \mathrm{C}$, in an atmosphere containing $5 \% \mathrm{CO}_{2}, 95 \%$ air and with a relative humidity of $98 \%$. The culture medium was a mixture $(1: 1)$ of EMED (an enriched Dulbecco's modified Eagle's medium) and FMED (modified Ham's F-12 nutrient mixture), containing $10 \%$ of foetal calf serum, $10^{4}$ units/liter penicillin and $10 \mathrm{mg} /$ liter streptomycin. The serum was stripped with activated charcoal to remove endogenous $1,25-(\mathrm{OH})_{2} \mathrm{D} 3$ as well as other compounds such as steroids or glucocorticoids. $1,25-(\mathrm{OH})_{2} \mathrm{D} 3$ $\left(10^{-6}-10^{-10} \mathrm{M}\right.$ final concentration, a gift from HoffmannLaRoche, Basel) was added in ethanol ( $0.1 \%$ final concentration). HMBA and NaBT were dissolved in PBS (1 M stock solutions). WiDr cells were grown for $48 \mathrm{~h}$, then the different substances were added for various time periods. The cell number added into petri dishes or multiwell plates was determined for each time point in order to reach $60-80 \%$ confluency after the selected incubation period.

\section{MTT assay}

Viable cells were counted using the MTT assay. In this colorimetric method, the dye 3-(4,5Dimethydiazol-2yl)-2,5-diphenyltetrazolium bromide (MTT) is reduced to a crystalline blue-coloured product (formazan) by intracellular dehydrogenases of viable cells. The crystals are then dissolved in DMSO and the solutions are photometrically measured at $546 \mathrm{~nm}$.

\section{Isolation of cytosolic and nuclear extracts from WiDr cells}

WiDr cells were grown in the presence or absence of $1,25-(\mathrm{OH})_{2} \mathrm{D} 3$ $\left(10^{-8} \mathrm{M}\right)$ or a combination of HMBA and NaBT ( $5 \mathrm{mM}$ each) for 48 or $96 \mathrm{~h}$, respectively. For the isolation of total soluble extracts, cells were washed with CMF-PBS, removed from the petri dishes with a cell scraper resuspended in buffer (2 mM EDTA, $3 \mu \mathrm{g} / \mathrm{ml}$ aprotinin (Trasylol ${ }^{\mathbb{R}}$, BAYER, Germany). Proteins were isolated by disrupting the cells by ultrasonication (Micro Ultrasonic Disrupter, Kontes) for $20 \mathrm{~s}$. The suspension was centrifuged $\left(13000 \mathrm{~g}, 4^{\circ} \mathrm{C}, 30 \mathrm{~min}\right)$ and the 
supernatant was used for Western blot experiments. For the isolation of nuclear soluble proteins, a method as previously described (Winsky and Kuznicki, 1995) was used. Briefly, resuspended WiDr cells (isolated as above) were homogenized in a teflon potter in a isotonic buffer (0.32 M sucrose, $5 \mathrm{mM}$ HEPES, $\mathrm{pH} 7.4$ ) including several protease inhibitors (soybean trypsin inhibitor, antipain, pepstatin, leupeptin, chymostatin, $10 \mu \mathrm{g} / \mathrm{ml}$ final, each, PMSF $1 \mathrm{mM}$ ) and centrifuged at $800 \mathrm{~g}$ for $10 \mathrm{~min}$. The crude nuclear pellets were resuspended in the same buffer and were layered on top of a solution (1.5 M sucrose, $5 \mathrm{mM}$ HEPES, $\mathrm{pH}$ 7.4) and centrifuged at $9200 \mathrm{~g}$ for $20 \mathrm{~min}$ resulting in a washed nuclear fraction. The nuclei were disrupted by ultrasonication and centrifuged as above and the supernatant was used for Western blot experiments. Protein concentrations of the different samples were determined by the method of Bradford using the reagents of Bio-Rad and bovine serum albumin as a standard.

\section{Western blot experiments}

Protein samples were separated by SDS - PAGE (12.5\%) on a Hoefer Mini-Gel system and proteins were transferred onto blotting membranes (Zeta Probe, Bio-Rad) using a Hoefer Semi-Dry blotting apparatus. The membranes were stained with Ponceau S $(0.1 \%(\mathrm{w} / \mathrm{v})$ in $5 \%(\mathrm{v} / \mathrm{v})$ acetic acid, Sigma) to check for even loading of the gels. Unspecific binding sites were saturated with blocking buffer (1\% (w/v) bovine serum albumin, $10 \%(\mathrm{v} / \mathrm{v})$ bovine serum in TBS), incubated with CR antibody (CR 7696 (Schwaller et al, 1993), 1:1 000 in blocking buffer), and further processed by the avidin-biotin method as described under immunocytochemistry, using 4-chlornaphtol/hydrogen peroxide as a chromogen. All Western blot experiments were repeated at least three times from independent experiments.

\section{Northern blot analysis}

Total RNA was isolated from control cells or from $1,25-(\mathrm{OH})_{2} \mathrm{D} 3-$ treated WiDr cells by the acid guanidinium-phenol-chloroform method (Chomczynski and Sacchi, 1987). $10 \mu \mathrm{g}$ of total RNA were separated on a $1 \%$ agarose/formaldehyde gel and was blotted onto Zeta Probe membranes. ${ }^{32} \mathrm{P}$-labelled probes were synthesised by random labelling of either a cDNA fragment of human CR (1500 bp) or actin (1000 bp). Probes were purified on Spin-Columns (Bio-Rad) and the specific activities were approximately $1 \times 10^{8} \mathrm{cpm} / \mu \mathrm{g}$. Membranes were incubated with the denatured probes in Church-Gilbert hybridising solution overnight at $65^{\circ} \mathrm{C}$ and washed with $2 \times \mathrm{SSC}$ at $\mathrm{RT}$ for $2 \mathrm{~h}$, followed by $2 \times \mathrm{SSC}$ at $65^{\circ} \mathrm{C}$ for $1.5 \mathrm{~h}$. Membranes were autoradiographed for up to 1 week at $-70^{\circ} \mathrm{C}$ using Kodak cassettes equipped with two intensifying screens.

\section{${ }^{3}[\mathrm{H}]$-thmyidine labelling}

For the incorporation of [methyl- $\left.{ }^{3} \mathrm{H}\right]$-thymidine $\left({ }^{3} \mathrm{H}\right.$-Thy), the cells were incubated with $1 \mu \mathrm{Ci} / \mathrm{ml}$ of ${ }^{3} \mathrm{H}$-Thy $(5 \mathrm{Ci} / \mathrm{mmol})$ in the culture medium at $37^{\circ} \mathrm{C}$ for $30 \mathrm{~min}$. After washing, cells were scraped off and once washed with PBS. Pelleted cells were resuspended in $20 \%(\mathrm{w} / \mathrm{v})$ TCA and the suspension was filtrated through GF/C filters (Whatmann). Filters were washed twice with cold $20 \%$ TCA and were counted in a scintillation counter.

\section{Overexpression of 6xHis-CR-22k in E. coli}

The cDNA clone CR16.17 (Schwaller et al, 1995) was cut with Sspl, the site was filled by Klenow enzyme and further digested with Ncol. Vector pDS56.1/RBSII 6xHis, Ncol-Hindlll(filled) was used to ligate the isolated fragment as described (Gander et al, 1996a). One litre cultures of TB medium were inoculated with overnight cultures of positive clones and at O.D.600nm of 0.7 , cultures were induced with IPTG ( $1 \mathrm{mM}$ final concentration). After $4 \mathrm{~h}$ incubation at $37^{\circ} \mathrm{C}$, E. coli were pelleted $\left(3000 \mathrm{~g}, 30 \mathrm{~min}, 4^{\circ} \mathrm{C}\right)$ and stored at $-20^{\circ} \mathrm{C}$. The pellets were solubilized in $8 \mathrm{M}$ guanidinium-hydrochloride and purified on a nickel chelate column as described before (Stüber et al, 1990). Fractions containing the fusion protein were analyzed by SDS - PAGE (12.5\%). Pure fractions were either dialysed against $10 \mathrm{mM}$ Tris, $\mathrm{pH}$ 7.5 or small portions were desalted on Sephadex PD-10 columns (Pharmacia, Uppsala). The identity of the recombinant protein was confirmed using electron spray ionisation-mass spectrometry (ESIMS, not shown).

\section{Immunohistochemistry}

WiDr cells were grown on glass cover slips and fixed in a mixture of $4 \%$ paraformaldehyde, $15 \%(\mathrm{v} / \mathrm{v})$ saturated picric acid, and $0.38 \%$ glutaraldehyde, in $0.1 \mathrm{M}$ Tris-buffered saline (TBS), $\mathrm{pH}$ 7.3. Cells were incubated with the first antibody [anti-CR 7696 (Schwaller et al, 1993) (1:5000) or 23B which recognizes the $15 \mathrm{C}$-terminal amino acids of CR-22k (Gander et al, 1996a) $(1: 1000-1: 2000)]$ in TBS containing $10 \%$ of foetal calf serum, for $72 \mathrm{~h}$ at $4{ }^{\circ} \mathrm{C}$. The second antibody (biotinylated goat anti-rabbit $\lg G$ ), diluted $1: 200$ was added for $2 \mathrm{~h}$ at RT, followed by an incubation with the avidin-biotin complex (VECTOR Laboratories Burlingame, CA), diluted 1:200. Finally, the antibody complex was visualised by incubation with the substrate $3,3^{\prime}$ diaminobenzidine (DAB)-HCl-hydrogen peroxide.

\section{ELISA}

For the quantification of CR and CR-22k a sandwich ELISA has been developed and is described in detail elsewhere (Schierle et al, 1996). Briefly, titer plates were coated with a goat polyclonal antiserum against CR. After blocking of unspecific binding sites, the isolated protein fractions (total soluble proteins or nuclear proteins) were added into the wells and incubated overnight at $4^{\circ} \mathrm{C}$. The bound antigens CR or CR-22k were detected either with the rabbit polyclonal antiserum 7696 against $C R$ or with a rabbit polyclonal antiserum against CR-22k (Gander et al, 1996a), respectively. After binding of the third antibody (goat anti-rabbit IgG, peroxidase-conjugated), the substrate tetramethylbenzidine $(\mathrm{TMB}) / \mathrm{H}_{2} \mathrm{O}_{2}$ was added and the colour reaction was quantified on a ELISA multiwell reader. For the calibration curves, purified human recombinant CR or CR-22k (50$800 \mathrm{pg} /$ well) was used.

\section{Acknowledgements}

The authors would like to thank M. Celio and T. Pauls from the Institute of Histology and General Embryology, University of Fribroug, Switzerland for the critical reading of the manuscript and for the helpful suggestions. The technical help of B. Fellay in the calcium measurements is highly appreciated. The work was supported by the Krebsliga Schweiz and the Krebsligen of the Cantons Ticino, Fribourg and Bern

\section{References}

Brehier A and Thomasset M (1988) Human colon cell line HT-29: characterisation of 1.25-dihydroxyvitamin D3 receptor and induction of differentiation by the hormone. J Steroid Biochem 29: 265-270

Chen TR (1987) Cancer Genet Cytogenet 27: 125-134

Chomczynski P and Sacchi N (1987) Single-step method of RNA isolation by acid guanidinium thiocyanate-phenol-chloroform extraction. Anal Biochem 162: 156-159 
Civitelli R, Kim YS, Gunsten SL, Fujimori A, Huskey M, Avioli LV and Hruska KA (1990) Nongenomic activation of the calcium message system by vitamin D metabolites in osteoblast-like cells. Endocrinol 127: 2253-2262

Cross HS, Hulla W, Tong WM and PeterlikM (1995) Growth regulation of human colon adenocarcinoma-derived cells by calcium, vitamin $\mathrm{D}$ and epidermal growth factor. J Nutr 125: 2004S-2008S

Feher JJ, Fullmer CS and Wassermann RH (1992) Role of facilitated diffusion of calcium by calbindin in intestinal calcium absorption. Am J Physiol 262: C517C526

Gagnon A, Simboli-Campbell M and Welsh J (1994) Induction of calbindin D-28K in Madin-Darby bovine kidney cells by 1,25(OH)2D3. Kidney Intern 45: 95-102

Gander J-C, Bustos-Castillo M, Stüber D, Hunziker W, Celio MR and Schwaller B (1996a) The calcium-binding protein calretinin-22k, an alternative splicing product of the calretinin gene is expressed in several colon adenocarcinoma cell lines. Cell Calcium 20: 63-72

Gander J-C, Gotzos V, Fellay B and Schwaller B (1996b) Inhibition of the proliferative cycle and apoptotic events in WiDr cells after down-regulation of the calciumbinding protein calretinin using antisense oligodeoxynucleotides. Exp Cell Res 225: $399-410$

Giuliano AR, Franceschi RT and Wood RJ (1991) Characterization of the vitamin D receptor from the Caco-2 human colon carcinoma cell line: effect of cellular differentiation. Arch Biochem Biophys 285: 261-269

Gotzos V, Schwaller B, Hetzel N, Bustos-Castillo M and Celio MR (1992) Expression of the calcium binding protein calretinin in WiDrcells and its correlation to their cell cycle. Exp Cell Res 202: 292-302

Gotzos V, Schwaller B, Gander J-Ch, Bustos-Castillo M and Celio MR (1996) Heterogeneity of expression of the calcium-binding protein calretinin in human colonic cancer cell lines. Anticancer Res 16: 3791-3798

Hannah SS and Norman AW (1994) $1 \alpha, 25(\mathrm{OH}) 2$ Vitamin D3-regulated expression of the eukariotic genome. Nutrition Rev 52: $376-382$

Kiraly E, Gotzos V and Celio MR (1993) In vitro detection of calretinin immunoreactivity in chicken embryo dorsal root ganglion neurons: a possible developmental marker. Dev. Brain Res 76: 260-263

Lointier P, Wargovich MJ, Saez S, Levin B, Wildrick DM and Boman BM (1987) The role of vitamin D3 in the proliferation of human colon cancer cell line in vitro. Anticancer Res 7: 817-822

Möckel V and Fischer G (1994) Vulnerability to excitotoxic stimuli of cultured rat hippocampal neurons containing the calcium-binding proteins calretinin and calbindin D28k. Brain Res 648: 109-120

Niendorf A, Arps H and Dietel M (1987) Effect of 1.25-dihydroxyvitamin D3 on human cancer cells in vitro. J Steroid Biochem 27: $825-828$

Norman AW, Nemere I, Zhou L et al (1992) 1a,25(OH)2D3, a steroid hormone that produces biologic effects via both genomic and non-genomic pathways. $J$ Steroid Biochem Mol Biol 41: 231 -241

PohI V, Rampelbergh JV, Mellaert S, Parmentier M and Pochet R(1992) Calretinin in rat ovary: an in situ hybridization and immunohistochemical study. Biochim Biophys Acta 1160: $87-94$

Résibois A and Rogers JH (1992) Calretinin in rat brain: an immunohistochemical study. Neurosci 46: 101-134
Schierle GS, Gander J-Ch, D'Orlando C, Celio MR and Vogt Weisenhorn DM (1996) Calretinin-immunoreactivity during postnatal development of the rat isocortex: a qualitative and quantitative study, Cerebral Cortex (in press)

Schroy P, Winawer S and Friedman E (1989) Effect on in vivo tumorigenicity of lengthy exposure of human colon cancer cells to the differentiation agent hexamethylene bisacetamide. Cancer Lett 48: 53-58

Schroy PC, Rustgl AK, Ikonomu E, Liu XP, Polito J, Andry C and O'Keane JC (1994) Growth and intestinal differentation are independently regulated in $\mathrm{HT} 29$ colon cancer cells. J Cell Physiol 161: 111-123

Schwaller B, Buchwald P, Blümcke I, Celio MR and Hunziker W (1993) Characterization of a polyclonal antiserum against the purified human recombinant calcium binding protein calretinin. Cell Calcium 14: 639-648

SchwallerB, Celio MR and HunzikerW (1995) Alternative splicing of calretinin mRNA leads to different forms of calretinin. Eur J Biochem.230: 424-430

Shabahang M, Buras RR, Davoodi F, Schumaker LM, Nauta RJ and Evans SRT (1993) 1.25-Dihydroxyvitamin D3 receptor as a marker of human colon carcinoma cell line differentiation and growth inhibition. Cancer Res. 53 : $3712-3718$

Siebert P, Hunziker W and Norman AW (1982) Cellfree translation analysis of the vitamin D-dependent calcium binding protein $m R N A$ activity present in total RNA and polysomal extracts from chick intestine. Arch Biochem Biophys 219: $286-$ 296

Strauss KI, Isaacs KR, Ha QN and Jacobowitz DM (1994) Calretinin is expressed in the Leydig cells of rat testis. Biochim Biophys Acta 1219: 435-440

Stüber D, Matile H and Garotta G (1990) System for high-level production in Escherichia coli and rapid purification of recombinant proteins: application to eptiope mapping, preparation of antibodies and structure-function analysis. In Immunological Methods, Lefkovitz I and Parnis B, eds. (New York: Academic press) pp. $121-152$

Tanaka Y, Bush KK, Eguchi T, Ikekawa N, Taguchi T, Kobayashi Y and Higgins PJ (1990) Effects of 1.25-dihydroxyvitamin D3 and its analogs on butyrate-induced differentiation of HT29 human colonic carcinoma cells and on the reversal of the differentiated phenotype. Arch Biochem Biophys 276: 415-423

Tanaka Y, Bush KK, Klauck TM and Higgins PJ (1989) Enhancement of butyrateinduced differentiation of HT-29 human colon carcinoma cells by 1.25 dihydroxyvitamin D3. Biochem Pharmacol 38: 3859-3865

Vandewalle B, Adenis A, Hornez L, Revillion F and Levebre J (1994) 1,25Dihydroxyvitamin D3 receptors in normal and malignant human colorectal tissues. Cancer Lett 86: 67-73

Vandewalle B, Wattez N and Lefebvre J (1995) Effects of vitamin D3 derivatives on growth, differentiation and apoptosis in tumoral colonic HT29 cells: possible implication of intracellular calcium. Cancer Lett 97: 99-106

Wali RK, Baum CL, Sitrin MD and Brasitus TA (1990) 1.25(OH)2 Vitamin D3 stimulates membrane phosphoinositide turnover, activates protein kinase $\mathrm{C}$ and increases cytosolic calcium in rat colonic epithelium. J Clin Invest 85 $1296-1302$

Winsky L and Kuznicki J (1995) Distribution of calretinin, calbindin-D28k and parvalbumin in subcellular fractions of rat cerebellum: effects of calcium. $J$ Neurochem 65: $381-388$ 